Отримано: 02 травня 2018 р.

Прорецензовано: 11 травня 2018 р.

Прийнято до друку: 20 травня 2018 р.

e-mail: tprykhodchenko@ukr.net

DOI: 10.25264/2311-5149-2018-9(37)-92-96
Приходченко Т. А. Реформування місцевого самоврядування в Україні: аналіз, досягнення та проблеми. Наукові записки Начіонального університету «Острозька академія». Серія «Економіка» : науковий журнал. Острог : Вид-во НаУОА, червень 2018. № 9(37). C. 92-96.

Приходченко Тетяна Анатоліївна,

кандидат економічних наук, доцент, докторант кафедри регіоналістики і туризму,

Київський національний економічний університет ім. В. Гетьмана

\title{
РЕФОРМУВАННЯ МІСЦЕВОГО САМОВРЯДУВАННЯ В УКРАЇНІ: АНАЛІЗ, ДОСЯГНЕННЯ ТА ПРОБЛЕМИ
}

Мета дослідження полягає у визначенні ролі децентралізації у проведенні реформування територіальної організації влади. Під час написання статті було описано різні підходи до поняття "децентралізація", оцінено ії придатність до сучасних українських реалій. Дослідження базувалося на використанні таких підходів і методів: системного, діалектичного, причинно-наслідкового методу, теоретичного узагальнення $і$ порівняння. Проведено аналіз сучасного прочесу реформування місиевого самоврядування в Україні, виявлено основні досягнення, проблеми та перспективи регіонального розвитку України.

Ключові слова: регіон, регіональний розвиток, державна регіональна політика, децентралізація влади, місиеве самоврядування.

\section{Приходченко Татьяна Анатольевна,}

кандидат экономических наук, дочент, докторант кафедры регионалистики и туризма, Киевский национальный экономический университет им. В Гетьмана

\section{РЕФОРМИРОВАНИЕ МЕСТНОГО САМОУПРАВЛЕНИЯ В УКРАИНЕ: АНАЛИЗ, ДОСТИЖЕНИЯ И ПРОБЛЕМЫ}

Цель исследования заключается в определении роли децентрализачии в проведении реформирования территориальной организации власти. При написании статьи были описаны различные подходы к понятию "децентрализачия", оченена ее пригодность к современным украинским реалиям. Исследование базировалось на использовании таких подходов и методов: системного, диалектического, причинно-следственного метода, теоретического обобщения и сравнения. Проведен анализ современного прочесса реформирования местного самоуправления в Украине, выявлены основные достижения, проблемы и перспективы регионального развития.

Ключевые слова: регион, региональное развитие, государственная региональная политика, децентрализация власти, местное самоуправление.

Tetyana Prykhodchenko,

Ph.D. in Economics, Associate Professor, Doctoral student, Department of regional science and tourism, Kyiv National Economic University named after Vadym Hetman

\section{THE REFORM OF LOCAL SELF-GOVERNMENT IN UKRAINE: ANALYSIS, ACHIEVEMENTS AND PROBLEMS}

The purpose of the study is to determine the role of decentralization in carrying out the reform of the territorial organization of government. The author of the article described different approaches to the concept of decentralization and assessed its suitability to the modern Ukrainian realities. The following methods were used in the research: systems approach, dialectical, causal-investigatory, theoretical generalization and comparison. The analysis of current process of local self-government reforming in Ukraine was carried out, the main achievements, problems and prospects of regional development were revealed.

Key words: the region, regional development, state regional policy, decentralization of power, local self-government.

Постановка проблеми. Функціонування місцевого самоврядування (МС) передбачає наявність ефективного управлінського механізму, який можна створити шляхом децентралізації влади. Водночас реформа децентралізації влади і державна регіональна політика мають одну мету - розвиток людського потенціалу. Своєю чергою, індекс регіонального людського розвитку й індекс конкурентоспроможності регіонів є двома головними показниками, за якими повинен бути оціненим кожен регіон України. 3 економічного погляду, збільшення повноважень територіальних громад (ТГ) і надання їм додаткових ресурсів - єдина реальна можливість відродити соціально-економічний розвиток регіонів. Це зумовлює 
необхідність аналізу ефективності процесу децентралізації та реформування МС в Україні, виявлення основних досягнень і проблем. Крім того, проблематика ще більше актуалізується в руслі сучасної адміністративно-територіальної реформи України.

Аналіз останніх досліджень і публікацій. Дослідженням процесів регіоналізації соціально-економічного розвитку, займались такі українські вчені: С. О. Біла, М. П. Бутко, В. М. Вакуленко, 3. С. Варналій, В. Є. Воротін, 3. В. Герасимчук, Я. А. Жаліло, Б. М. Данилишин, М. І. Долішній, Ф. Д. Заставний, Л. Л. Ковальська, Ю. В. Ковбасюк, В. С. Коломійчук, Л. Г. Чернюк, Л. Т. Шевчук, С. Л. Шульц та інші. Сутності децентралізації, а також проблемам підвищення ефективності реформування МС в Україні приділяли певну увагу ряд дослідників, а саме: Т. М. Безверхнюк, Р. П. Безсмертний, О. М.Бориславська, К. О. Ващенко, І. А. Грицяк, Р. Ю. Гришко, Ю. І. Ганущак, В. Ю. Керецман, Ю. В. Ковбасюк, Р. А. Колишко, О. Л. Копиленко, А. П. Лелеченко, П. Ф. Мартиненко, А. С. Матвієнко, Н. Р. Нижник, Н. Г. Плахотнюк, А. Ф. Ткачук, В. В. Толкованов, М. В. Харитончук та інші. Слід зазначити, що, незважаючи на висвітлення науковцями проблеми реалізації структурної складової механізмів децентралізації в МС, питання змін в імплементації підходів до механізмів децентралізації та складової впливу децентралізації на трансформацію повноважень ТГ вимагають подальшого дослідження.

Мета і завдання дослідження полягають у визначенні ролі децентралізації у проведенні реформування територіальної організації влади. У статті проведено аналіз сучасного процесу реформування МС в Україні, виявлено досягнення та проблеми регіонального розвитку в умовах подальшого реформування МC, надано пропозиції щодо підвищення ефективності та розвитку МС в Україні.

Виклад основного матеріалу. Децентралізація означає такий спосіб визначення та розмежування завдань і функцій, за якого більшість із них передається з рівня центральних органів на рівень нижчий і стає власним завданням і повноваженням органів нижчого рівня. До ііі ознак належать: максимальна наближеність до об'єктів; самостійність прийняття рішень; забезпеченість ресурсами; доступність громадської участі та контролю; саморегулювання; відповідна інституційна організація. По суті вона є системою, що містить безліч елементів, які послідовно реалізуються в процесі функціонування влади. Тобто децентралізація державного управління може бути принципом управлінського впливу; способом (методом) управління; управлінським режимом; формою організації публічної влади та публічного управління; процес розподілу та реалізації повноважень; елементом організаційної структури публічного управління.

Децентралізація розкривається через такі ії сутнісні характеристики: по-перше, передані МС державою функції з організації життєдіяльності на місцевому рівні виконуються органами, які підпорядковані, підзвітні і підконтрольні більшою мірою громаді, ніж місцевій державній адміністрації, що гарантує певну організаційну незалежність у прийняті управлінського рішення; по-друге, представницькі органи ТГ як виразники їхніх інтересів зацікавлені виконувати надані державою функції з максимальною для них вигодою, що гарантує вищу якість, а значить й ефективність надаваних послуг; по-трете, демократичність формування органів МC дає змогу широко залучати населення до врегулювання суспільних відносин, що гарантує формування основ демократичного ладу в країні; по-четверте, держава не втручається в роботу органів МС, а лише контролює іiі в межах дотримання вимог нормативно-правової бази країни [1, с. 37]. Отже, децентралізація - це передача повноважень і бюджетних надходжень від державних органів до органів МС. Метою реформи $\mathrm{MC} \epsilon$, передусім, забезпечення його спроможності самостійно, за рахунок власних ресурсів, вирішувати питання місцевого значення (наділення ТГ більшими ресурсами та мобілізація їх внутрішніх резервів).

На думку академіка НАН України Богдана Данилишина, тільки децентралізація зможе зробити Україну сучасною державою нового промислового розвитку зі стійким зовнішньополітичним становищем, тому що ефективні економічні реформи без участі народу не відбудуться, а ефективна участь народу в політичних і економічних реформах у межах централізованого управління економічним життям в країні при тому, що центральні органи всіляко саботують проведення реформ, неможлива [2]. Ю. В. Ковбасюк, К. О. Ващенко, В. В. Толкованов у своїх працях зазначають, що в умовах глобальних змін, які відбулися останнім часом, розвиток МС є одним із пріоритетних напрямів української державної політики. Розвиток держави неможливий без розвитку регіонів від того, наскільки сильною є регіональна влада, як вона забезпечує надання соціальних послуг населенню, настільки сильною $є$ держава. Розуміючи важливість цієї проблеми, на сучасному етапі розвитку всіх гілок влади постає питання про необхідність удосконалення теорії та практики сучасного державотворення, зумовленого трансформаціями в політичній системі суспільства, проведенням адміністративно-територіальних, регіональних реформ, упровадженням конструктивного соціального партнерства між центром і територіями. Проблема модернізації сучасної системи МС в Україні набуває нового концептуального змісту. Її розв'язання сприятиме вирішенню важливих для населення питань у межах регіону [1, с. 3].

Український уряд 1 квітня 2014 року ухвалив Концепцію реформи МС і територіальної організації влади, що стала стартом важливої для України реформи - децентралізації влади [3]. Фактично 2014-2015 роки стали роками бурхливого старту децентралізації та реформи державної регіональної політики. Протягом двох років було ухвалено все необхідне для добровільного об'єднання громад базове законодавство, здійснено реформу 
міжбюджетних відносин, проведено децентралізацію у сфері надання адміністративних послуг, сформовано законодавство щодо державної регіональної політики та фінансування регіонального розвитку не на основі лобізму та лояльності до правлячої партії, а на основі формули, підходів і найкращих практик ЄС. За темпами добровільного процесу укрупнення одиниць базового рівня МС Україна показала дуже хороші результати. У результаті бюджетної децентралізації МС істотно збільшило свої бюджети, а бюджети об'єднаних територіальних громад (ОТГ) зросли в кілька разів. Водночас реформа децентралізації на сучасному етапі розвитку України ввійшла в таку стадію, що головний критерій - уже не кількість ОТГ, а якісні показники - скільки людей об’єдналось, яку територію охоплюють ОТГ в області (зараз понад 6 млн українців), тому що більша територія дозволяє реалізувати більше інфраструктурних проектів і перспектива ОТГ щодо залучення інвестицій, підвищення іiї конкурентоздатності та привабливості для людей збільшується.

Отже, проаналізуємо основні досягнення України щодо сучасного процесу децентралізації влади та реформування МС. На основі розробленої Міністерством регіонального розвитку, будівництва та ЖКГ України методики визнання рейтингу областей за формуванням спроможних ТГ, простежимо динаміку формування ОТГ із 2015 по 2018 рр. У цьому рейтингу взято п’ять основних параметрів: 1) кількість ОТГ; 2) площа покриття ОТГ території області; 3) кількість ТГ, що об’єднались; 4) кількість ОТГ із чисельність менше 5 тис. осіб; 5) відсоток охоплення області за перспективним планом (таблиця 1).

В Україні на сьогодні вже функціонує 665 ОТГ, у 40 ОТГ вибори призначені на 29.04. 2018 р., а 23 громади очікують на рішення ЦВК, тобто разом утворено: 728 ОТГ. $Є 1188$ ОТГ у перспективних планах, затверджених українським урядом, які об'єднують 72,5\% території України [4]. Динаміка збільшення ОТГ в Україні за три роки реформи місцевого самоврядування наступна: у 2015 р. було створено 159 ОТГ; у 2016 р. - 366 ОТГ (+201); у 2017 р. - 665 ОТГ (+299); у 2018 р. - 728 (+63). Чисельність жителів в ОТГ у 2015 р. складала 1,4 млн осіб; у 2016 р. - 3,1 млн осіб $(+1,7)$; у 2017 р. - 5,6 млн осіб $(+2,5)$; у 2018 р. $-6,3$ млн осіб $(+0,7)$ або 14,9\% від загальної чисельності населення України. Площа ОТГ (тис. кв. км.) за ці роки збільшувалася так: у 2015 р. - 36,5; у 2016 р. - 84,2 (+47,7); у 2017 р. - 164,1 $(+79,9)$; у 2018 р. - 179,2 (+15,1) або 31,1\% від загальної площі України [5].

Таблиия 1

Динаміка формування об'сднаних територіальних громад в Україні

\begin{tabular}{|c|c|c|c|c|c|c|c|c|c|}
\hline \multirow[b]{2}{*}{ Назва регіону } & \multirow[b]{2}{*}{$\begin{array}{c}\text { Загаль- } \\
\text { ний } \\
\text { рей- } \\
\text { тинг }\end{array}$} & \multicolumn{5}{|c|}{ Загальне місце за основними параметрами } & \multicolumn{3}{|c|}{ Приєднання громад до ОТГ } \\
\hline & & $\begin{array}{c}\text { За } \\
\text { к-стю } \\
\text { ОТГ }\end{array}$ & $\begin{array}{c}\text { За } \\
\text { покрит- } \\
\text { тям ОТГ } \\
\text { площі } \\
\text { області }\end{array}$ & $\begin{array}{c}\text { За к-стю } \\
\text { ТГ, що } \\
\text { об’сдна- } \\
\text { лися }\end{array}$ & $\begin{array}{c}\text { За к-стю } \\
\text { ОТГ з } \\
\text { чисельн. } \\
\text { менше } \\
5 \text { тис. осіб }\end{array}$ & $\begin{array}{c}\text { За \% пло- } \\
\text { щі області, } \\
\text { охопленої } \\
\text { перспект. } \\
\text { планом }\end{array}$ & $\begin{array}{c}\text { К-сть } \\
\text { ОТГ }\end{array}$ & $\begin{array}{c}\text { К-сть } \\
\text { ОТГ, } \\
\text { до яких } \\
\text { приєдну- } \\
\text { ються }\end{array}$ & $\begin{array}{c}\text { К-сть } \\
\text { ТГ, які } \\
\text { присдну- } \\
\text { ються до } \\
\text { ОТГ }\end{array}$ \\
\hline Житомирська & 1 & 2 & 1 & 1 & 10 & 11 & 45 & 6 & 14 \\
\hline Хмельницька & 2 & 6 & 4 & 2 & 7 & 9 & 39 & & \\
\hline Дніпропетровська & 3 & 1 & 3 & 4 & 18 & 3 & 56 & 5 & 8 \\
\hline Запорізька & 4 & 3 & 2 & 3 & 22 & 4 & 36 & 2 & 4 \\
\hline Волинська & 5 & 6 & 6 & 6 & 14 & 6 & 40 & 3 & 3 \\
\hline Чернігівська & 6 & 7 & 5 & 5 & 13 & 12 & 37 & 4 & 13 \\
\hline Сумська & 7 & 9 & 9 & 9 & 12 & 5 & 28 & 2 & 2 \\
\hline Чернівецька & 8 & 10 & 8 & 8 & 6 & 17 & 26 & 3 & 3 \\
\hline Рівненська & 9 & 11 & 14 & 13 & 11 & 1 & 25 & & \\
\hline Херсонська & 10 & 11 & 11 & 11 & 15 & 8 & 26 & 1 & 2 \\
\hline Миколаївська & 11 & 10 & 10 & 10 & 17 & 10 & 28 & 2 & 3 \\
\hline Івано-франківська & 12 & 13 & 19 & 16 & 2 & 7 & 23 & & \\
\hline Тернопільська & 13 & 5 & 7 & 7 & 19 & 21 & 40 & & \\
\hline Харківська & 14 & 15 & 22 & 20 & 1 & 2 & 12 & 1 & 1 \\
\hline Одеська & 15 & 11 & 12 & 14 & 4 & 22 & 25 & 1 & 1 \\
\hline Львівська & 16 & 8 & 18 & 17 & 9 & 13 & 35 & & \\
\hline Донецька & 17 & 16 & 15 & 15 & 5 & 14 & 9 & & \\
\hline Полтавська & 18 & 4 & 13 & 12 & 23 & 19 & 39 & 1 & 4 \\
\hline Кіровоградська & 19 & 14 & 21 & 21 & 16 & 1 & 13 & & \\
\hline Луганська & 20 & 17 & 16 & 17 & 8 & 16 & 8 & 1 & 1 \\
\hline Черкаська & 21 & 12 & 17 & 18 & 20 & 15 & 26 & 3 & 4 \\
\hline Київська & 22 & 17 & 23 & 22 & 3 & 18 & 9 & & \\
\hline Вінницька & 23 & 8 & 20 & 19 & 21 & 20 & 34 & 4 & 13 \\
\hline Закарпатська & 24 & 18 & 24 & 23 & 1 & 23 & 6 & & \\
\hline PA3ОM & - & - & - & - & - & - & 665 & 39 & 76 \\
\hline
\end{tabular}

Джерело: складено автором за [5], [6]. 
Сьогодні областями-лідерами за покриттям громадами території області є: Житомирська (площа створених ОТГ більше половини області), Волинська, Дніпропетровська, Тернопільська, Чернігівська, Чернівецька. Серед регіонів-аутсайдерів зі створення ОТГ - Закарпатська, Київська, Харківська, Кіровоградська, Івано-Франківська області. А Одеська область має найбільшу кількість районів, де не створено жодного ОТГ. Отже, можна простежити і якість процесів об'єднання, і перспективу. П’ятірка лідерів за загальним рейтингом - Житомирська, Хмельницька, Дніпропетровська, Запорізька та Волинська області. П'ятірка аутсайдерів: Закарпатська, Вінницька, Київська, Черкаська та Луганська області. Вже 726 громад активно співпрацюють у різних сферах, тобто скористалися інструментом співробітництва громад. Лідером у міжмуніципальному співробітництві залишається Полтавська область, де близько 300 громад спільно вирішують питання переважно у сферах ЖКГ, пожежної безпеки, освіти, охорони здоров'я. Загалом із 2015 по 2018 роки кількість ТГ, що утворили ОТГ змінювалась так: у 2015 р. - 804 ТГ; у 2016 р. - 1747 ТГ (+943); у 2017 р. - 3124 ТГ (+1377); у 2018 р. - 3378 ТГ (+254) об’єдналися у 728 ОТГ (30,1\% від загальної кількості рад базового рівня станом на 01.01.2015р.) [5]. Але зараз існує серйозна проблема, яку треба якнайшвидше вирішити - 152 районів (із 468), у яких не створено жодної ОТГ. I це насамперед дискримінація українців, які, проживаючи в громаді, залишаються обмеженими у фінанcax, pecyрсах, можливостях впливати на свій розвиток і планувати майбутнє. Тому головне завдання для України полягає в тому, щоб не залишилось районів без жодної громади. На сьогодні в Україні вже затверджено перспективні плани формування територій громад 23 областей (1200 ОТГ, які об’єднають 7855 ТГ або 73,4\% від загальної площі України) [5].

На 2017 рік для фінансування проектів регіонального розвитку в регіонах у державному фонді регіонального розвитку (ДФРР) було передбачено 3,5 млрд грн. Із них 1 млрд грн - це кошти загального фонду ДБУ, 2,5 млрд грн - спеціальний фонд [7]. А у 2018 році уряд України ще виділить 11 млрд грн на розвиток регіонів. Водночас варто зауважити, що використання коштів ДФРР у 2017 році відбувалося із значною затримкою. Але збільшення коштів місцевих бюджетів, коштів ДФРР, субвенції на соціальноекономічний розвиток окремих територій і субвенції формування інфраструктури ОТГ при відсутності інституційної спроможності органів влади до системного планування, а також неспроможності місцевого підприємництва до виконання такого обсягу робіт може привести до невикористання виділених коштів, а відтак до спроби їх централізації. 3 проведенням бюджетної децентралізації, частка обласних бюджетів у зведеному бюджеті України знижується, проте зростає його роль у власне стимулюванні регіонального розвитку через забезпечення з обласного бюджету співфінансування проектів регіонального розвитку, що фінансуються з ДФРР. Україна у 2017 році почала реалізацію проектів розвитку в регіонах за 5 програмами за кошти ЄС на підтримку регіонального розвитку в сумі понад 630 млн грн [8].

Отже, загальними трендами, що впливали на сучасний регіональний розвиток України загалом, і реформування місцевого самоврядування зокрема, були:

- продовження війни на сході країни, іiі дестабілізаційний вплив на решту України, як економічного, так і політичного та соціального характеру;

- стабілізація економічної ситуації, деяке зростання ВВП та пожвавлення окремих галузей економіки України на фоні шокової ситуації 2014 року (у 2017 році ВВП України зріс на 2,5\%, а промисловість на 3\%; середня заробітна плата сягнула близько 7 тис. грн на місяць; ознакою позитивних змін $є$ також підвищення позиції України у Міжнародному рейтингу Doing Business; отримано протягом 2017 року 366 млрд грн капітальних інвестицій, що на 22\% більше, ніж у 2016 році; переорієнтовано країну на ринки $\mathrm{CC}$ та Азії, причому зараз поставляється не тільки сировина, а й готова продукція);

- продовження процесів добровільного об'єднання ТГ і поява нових особливостей у цих процесах (рівень власних доходів загального фонду обласних бюджетів за 2017 р., порівняно з 2016 р., зріс на 6,2 млрд грн (+31,2\%), із 19,9 млрд грн до 26,1 млрд грн. Обласні бюджети отримали у 2017 р. міжбюджетних трансфертів із державного бюджету - 75,1 млрд грн) [9];

- проведення низки заходів національного рівня, присвячених питанням регіонального розвитку та децентралізації, зокрема: проведено фінансову та податкову децентралізацію.

Висновки. Під час написання цієї статті було описано різні підходи до поняття «децентралізація», оцінено іï придатність до сучасних українських реалій і виявлено найбільш збалансований підхід щодо реформування МС в Україні. Підсумовуючи проведене дослідження, зробимо висновки. По-перше, процеси децентралізації влади властиві всім європейським державам. По-друге, в Україні існують можливості домогтися такого співвідношення централізації та децентралізації влади за правовим та економічним регулюванням, при яких політична спільнота та загалом українське суспільство не тільки зберігаються, але і прогресивно розвиваються. Таким чином, децентралізація - не просто перерозподіл повноважень між органами державної влади та $\mathrm{MC}$, це суспільний проект, який має ціннісні виміри. Водночас для різних соціальних груп такі виміри можуть не збігатися. Сьогодні в Україні існують суперечності впливів децентралізації й укрупнення громад у коротко- та середньостроковій перспективі, тому необхідні дії влади в напрямі розробки символічних смислів децентралізації, які дали б змогу сформувати довіру 
до неї. Зокрема, слід посилити ті елементи політики децентралізації, які здатні сприяти узгодженню їі символічних смислів. У цьому контексті певний потенціал має політика децентралізації в гуманітарній сфері. Можна стверджувати, що політика регіонального розвитку в сучасній Україні не буде ефективною, якщо не забезпечити: чітке розмежування повноважень і відповідальності між регіонами та центром, а також між внутрішньорегіональними рівнями влади; фінансову самостійність чи достатність місцевих бюджетів для виконання органами МС їх повноважень; стимулювання розвитку слабких регіонів і регіонів із складними природними умовами через фіскальне й інвестиційне сприяння. Лише забезпечивши перші дві умови, можна розраховувати на ефективність заходів стимулювання розвитку. Для подальшого розвитку МС в Україні необхідним є:

- розподіл повноважень між усіма органами влади згідно регіональних та місцевих потреб (гнучка імплементація вирішення нагальних проблем);

- створення умов для повноцінного функціонування МС, зокрема фінансової відповідальності за прийнятті рішення та надання можливості збільшувати свої ресурси (фіскальні й економічні механізми мотивації збільшення капіталізації діяльності підприємців);

- надання економічної автономії для створення умов інвестиційної привабливості (виявлення секторних можливостей розвитку та надання преференцій інвестору, що наддасть найкращий шлях інновацій для збільшення економічного потенціалу регіону);

- прямий діалог органів МС і його населення (надання можливості населенню регіону впливати на нормативно-правові рішення місцевих органів).

\section{Література:}

1. Ковбасюк Ю.В., Ващенко К.О., Толкованов В.В. Місцеве самоврядування в Україні: сучасний стан та основні напрями модернізації. Київ, 2014. 128 с.

2. Данилишин Б. Что необходимо Украине для экономического чуда / Новое время. 2016. 25 мая. URL: https://nv.ua/opinion/danylyshyn/chto-neobhodimo-ukraine-dlja-ekonomicheskogo-chuda-131963.html (дата звернення: 10.04.2018).

3. Про схвалення Концепції реформування місцевого самоврядування та територіальної організації влади в Україні: Розпорядження КМУ № 333-р від 01.04.2014 р. // База даних «Законодавство України» / ВР України. URL: http://zakon5.rada.gov.ua/laws/show/333-2014-p (дата звернення: 11.04.2018).

4. Хто з областей в лідерах, а хто в аутсайдерах у впровадженні децентралізації - дані Мінрегіону / Децентралізація. 2018. 13 квітня. URL: http://decentralization.gov.ua/news/8664 (дата звернення: 14.04.2018).

5. Моніторинг процесу децентралізації влади та реформування місцевого самоврядування (станом на 12 березня 2018 р.) / Офіційний сайт Міністерства регіонального розвитку, будівництва та ЖКГ України. URL: http://www.minregion.gov.uа (дата звернення: 13.04.2018).

6. Регіональна статистика України / Офіційний сайт Державної служби статистики України. URL: http:// www.ukrstat.gov.ua (дата звернення: 12.04.2018).

7. Аналітичний звіт «Регіональний розвиток України (січень-жовтень 2017) / Децентралізаиія. 2018. 30 січня. URL: http://decentralization.gov.ua/news/8127 (дата звернення: 15.04.2018).

8. Ткачук А. Як швидко можна зруйнувати те, що лише стає на ноги / Інститут Громадянського Суспільства. 2017. 15 листопада. URL: https://www.csi.org.ua/news/yak-shvydko-mozhna-zrujnuvaty-te-shho-lyshestaye-na-nogy (дата звернення: 08.04.2018).

9. «Агенції регіонального розвитку треба розглядати як перспективні стартапи...» / Децентралізаиія. 2018. 19 січня. URL: http://decentralization.gov.ua/news/8057 (дата звернення: 05.04.2018). 